\title{
大変形正負交番載荷を受ける $\mathrm{RC}$ 柱の 損傷状況及び補修効果に関する実験的研究
}

\author{
石橋忠良 $^{1} \cdot$ 津吉毅 $^{2} \cdot$ 小林薫 $^{3} \cdot$ 小林将志 $^{4}$ \\ 1フェロー会員 工博 東日本旅客鉄道株式会社 建設工事部 構造技術センター 所長 \\ (广151-8578 東京都渋谷区代々木 2-2-2) \\ ${ }^{2}$ 正会員 東日本旅客鉄道株式会社 建設工事部構造技術センター 副課長 （同上） \\ ${ }^{3}$ 正会員 東日本旅客鉄道株式会社 建設工事部構造技術センター（同上） \\ ${ }^{4}$ 正会員 工修 東日本旅客鉄道株式会社 上信越工事事務所 工事管理・安全担当課
}

(广370-8543 高崎市栄町 6-26)

\begin{abstract}
コンクリート構造物の耐震設計を合理的に行うためには, 地震時の部材の塑性変形レベルに応じた損傷 状況を適切に把握する必要がある. 本文では, 実際の鉄道ラーメン高架橋柱を想定したじん性率 10 程度 以上の高い変形性能を有する $\mathrm{RC}$ 柱の静的正負交番載荷試験結果から, 部材の塑性変形レベルと部材の損 傷状態の相関, 損傷範囲等をとりまとめ, 損傷状態に対しては, 主として補修の難易度の観点から評価を 行った. また, 塑性率 10 程度以上の塑性変形レベルで損傷を受けた試験体を補修し, 補修した試験体に よる正負交番載荷試験により, 補修後も十分な工神ギ -吸収能力を有することを確認した.
\end{abstract}

Key Words: seismic resistant design, reversal cyclic loading, reinforced concrete column, damage, repair

\section{1. はじめに}

鉄道コンクリート構造物の耐震設計には, 従来から 構造物の変形性能を考慮したじん性設計を採用して いる ${ }^{1)}$.このじん性を考慮した設計は，コンクリー 卜構造物が塑性化した後の挙動も考慮し, 塑性変形 性能により構造物に作用する地震動のエネルギーを 吸収させるものであり, 部材がある程度の損傷（塑 性化）を受けることを前提としている．一方，構造 物の耐震性能は, その重要度に応じて, 復旧の難易 度等を考慮して定義され2)，3），要求される耐震性 能に応じて, 復旧の難易度に影響を与える部材の損 傷程度を制御する必要がある. したがって, 耐震設 計を合理的に行うためには，構造物（部材）の地震 による塑性変形レベルと損傷状態の相関を明確に把 握する必要がある.

著者らは, 鉄道ラーメン高架橋柱を想定した,
じん性率 10 程度以上の大きな変形性能を有する RC 試験体を用いた静的正負交番載荷試験を行い，塑性 変形レベルと損傷程度の相関, 損傷範囲について評 価を行った ${ }^{4)}$.

本文では，損傷状況に各種要因の与える影響に ついて考察を加えた．さらに復旧の難易度と密接に 関連している損傷レベルと塑性変形レベルとの関係 について検討した. また, じん性率 10 以上の大き な塑性変形領域で損傷を受けた R C 試験体を数種類 の方法で補修し, 補修後の試験体を用いた正負交番 載荷試験を行い, 補修効果および変形性能を確認し た結果 ${ }^{5)}$ をわせて報告する.

\section{2. 実験概要}

\section{（1）試験体諸元}

表一 1 に試験体諸元を示す. 図ー 1 に試験体断 
表 -1 試験体諸元

\begin{tabular}{|c|c|c|c|c|c|c|c|c|c|c|}
\hline 試験体No. & \begin{tabular}{|c|} 
断面寸法 \\
B $\times$ H \\
$(\mathrm{mm})$
\end{tabular} & $\begin{array}{c}\text { 有效高 } \\
\mathrm{d} \\
(\mathrm{mm})\end{array}$ & $\begin{array}{c}\text { せん断スパン比 } \\
\mathrm{a} / \mathrm{d}\end{array}$ & $\begin{array}{l}\text { 軸方向鉄筋 } \\
\text { (径) } \times \text { (本) }\end{array}$ & 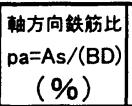 & $\begin{array}{l}\text { 側鉄筋 } \\
\text { (径) } \times \text { (本) }\end{array}$ & 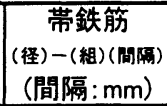 & \begin{tabular}{|c|} 
帯鉄筋比 \\
ps \\
$(\%)$
\end{tabular} & 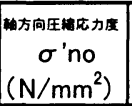 & 显荷バターン \\
\hline$I-1$ & $400 \times 400$ & 360 & 3.19 & D19 $\times 16$ & 2.865 & $\mathrm{D} 19 \times 3$ & D13-1ctc125 & 0.507 & 0.98 & $\bar{A}$ \\
\hline$I-2$ & $400 \times 400$ & 360 & 3.19 & D19 $\times 16$ & 2.865 & $D 19 \times 3$ & D13-1ctc 70 & 0.905 & 0.98 & $\bar{A}$ \\
\hline$I-3$ & $400 \times 400$ & 360 & 3.19 & D19 $\times 16$ & 2.865 & D19 $\times 3$ & D13-1 ctc 40 & 1.584 & 0.98 & $\bar{A}$ \\
\hline II -1 & $400 \times 400$ & 360 & 3.19 & D16 $\times 16$ & 1.986 & D16 $\times 3$ & D13-1 ctc 90 & 0.704 & 0.49 & A \\
\hline II -2 & $400 \times 400$ & 360 & 3.19 & $\times 16$ & 986 & D16 $\times 3$ & D13-1 ctc 50 & 1.267 & 1.96 & $\bar{A}$ \\
\hline III -1 & $400 \times 600$ & 550 & 2.09 & D13 $\times 12$ & 0.634 & $D 13 \times 2$ & D13-1ctc 90 & 0.704 & 0.98 & A \\
\hline III -2 & $400 \times 350$ & 300 & 4.17 & $\mathrm{D} 22 \times 16$ & 4.424 & D22 $\times 3$ & D13-1ctc 90 & 0.704 & 0.98 & $\mathrm{~A}$ \\
\hline III -3 & $350 \times 350$ & 310 & 3.83 & D19 $\times 16$ & 3.742 & D19 $\times 3$ & D16-1ctc 50 & 2.270 & 4.90 & $A$ \\
\hline A 1 & $400 \times 400$ & 360 & 3.19 & $\times 16$ & 65 & D19 $\times 3$ & D13-1 ctc 80 & 0.792 & 0.98 & $\mathrm{~B}$ \\
\hline A 2 & $400 \times 400$ & 360 & 9 & 16 & 5 & D19 $\times 3$ & D13-1ctc 60 & 1.056 & 0.98 & $B$ \\
\hline A 3 & $400 \times 400$ & 360 & 3.19 & 16 & 36 & D16 $\times 3$ & D13-1ctc 70 & 0.905 & 0.49 & $B$ \\
\hline A 4 & $400 \times 400$ & 360 & 19 & 16 & 67 & $\mathrm{D} 13 \times 3$ & D13-1ctc 80 & 0.792 & 0.98 & $\mathrm{~B}$ \\
\hline A 5 & $400 \times 400$ & 360 & 3.19 & $\times 16$ & 1.267 & D13 $\times 3$ & D13-1ctc140 & 0.453 & 0.98 & $\mathrm{~B}$ \\
\hline A 6 & $400 \times 400$ & 360 & 3.19 & $\times 16$ & 2.865 & D19 $\times 3$ & D13-1ctc 50 & 1.267 & 0.98 & $\mathrm{~B}$ \\
\hline A 7 & $400 \times 400$ & 360 & 3.19 & D19 $\times 16$ & 2.865 & D19 93 & D13-1 ctc 60 & 1.056 & 0.98 & $\mathrm{~A}$ \\
\hline A 8 & $400 \times 400$ & 360 & 3.19 & D16 $\times 16$ & 1.986 & D16 $\times 3$ & D13-1ctc120 & 0.528 & 0.98 & $B$ \\
\hline A 9 & $400 \times 400$ & 360 & 3.19 & $\times 16$ & 2.865 & D19 $\times 3$ & D16-1ctc 60 & 1.655 & 0.98 & $\mathrm{~B}$ \\
\hline A 10 & $400 \times 700$ & 660 & 1.52 & & & D19 $\times 4$ & D13-1ctc 60 & 1.056 & 0.98 & $\bar{B}$ \\
\hline A 11 & $500 \times 500$ & 460 & 2.8 & & & D19 $\times 3$ & D13-1ctc 60 & 0.845 & 0.98 & B \\
\hline No. 6 & $400 \times 400$ & 360 & 3.19 & $\times 16$ & 2.865 & D19 13 & D13-1ctc 60 & 1.056 & 0.98 & $B$ \\
\hline$A 1(R)$ & $400 \times 400$ & 360 & 3.19 & D19 $\times 16$ & 2.865 & $D 19 \times 3$ & D13-1ctc 80 & 0.792 & 0.98 & $\mathrm{C}$ \\
\hline$A 2(R)$ & $400 \times 400$ & 360 & 3.19 & $\mathrm{D} 19 \times 16$ & 2.865 & D19 $\times 3$ & D13-1ctc 60 & 1.056 & 0.98 & C \\
\hline A3(R) & $400 \times 400$ & 360 & 3.19 & D16 $\times 16$ & 1.986 & D16 $\times 3$ & D13-1ctc 70 & 0.905 & 0.49 & $B$ \\
\hline A9(R) & $400 \times 400$ & 360 & 3.19 & D19 16 & 2.865 & $019 \times 3$ & D16-1ctc 60 & 1.655 & 0.98 & $B$ \\
\hline
\end{tabular}

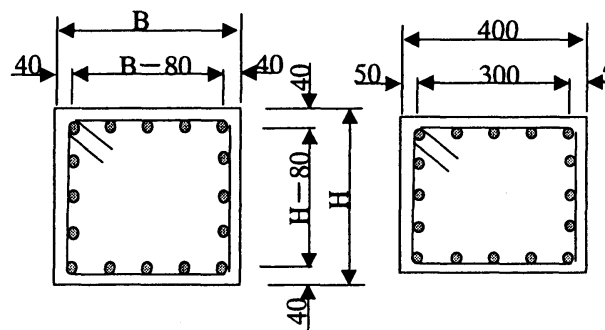

(a) I , II, III $-3, A 1 \sim A 9$, A11, No. 6 試験体 (b) III-2 試験体

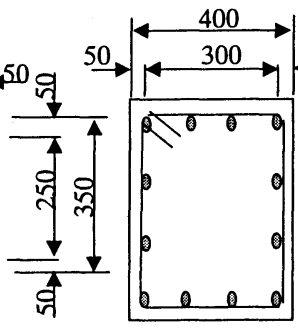

(c) III -1 試験体

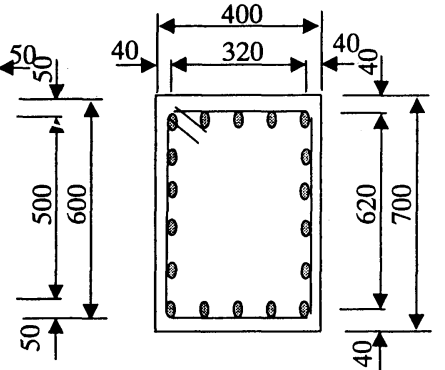

(d) $\mathrm{A} 10$ 試験体

図 - 1 試験体断面図

表一 2 材料強度, 耐力比の計算值, 実験結果

\begin{tabular}{|c|c|c|c|c|c|c|c|c|c|c|}
\hline \multirow[b]{2}{*}{$\begin{array}{c}\text { 試験体 } \\
\text { No. }\end{array}$} & \multicolumn{3}{|c|}{ 材料強度 } & \multicolumn{3}{|c|}{ 訐至值 } & \multicolumn{3}{|c|}{ 実鐾值 } & \multirow[b]{2}{*}{ 破壊形態 } \\
\hline & $\begin{array}{l}\text { コンクリート } \\
\text { 压縮強度 } \\
\left(\mathrm{N} / \mathrm{mm}^{2}\right)\end{array}$ & 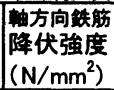 & $\begin{array}{c}\text { 带鉄筋 } \\
\text { 降伏強度 } \\
\left(\mathrm{N} / \mathrm{mm}^{2}\right)\end{array}$ & $\mathrm{Vc} / \mathrm{Vmu}$ & $\mathrm{Vs}_{\mathrm{s}} / \mathrm{Vmu}$ & $\begin{array}{c}\text { 耐力比 } \\
V_{y d} / V m u\end{array}$ & $\mid \begin{array}{c}\text { L゙ん性率 } \\
\mu\end{array}$ & $\begin{array}{l}\text { 回転中心 } \\
\mathrm{h} 1(\mathrm{~cm})\end{array}$ & $\begin{array}{c}\text { 損偍集中 } \\
\text { 笵囲長 } \\
\mathrm{h} 2(\mathrm{~cm})\end{array}$ & \\
\hline$I-1$ & 27.4 & 378.3 & 359.1 & 0.66 & 0.89 & 1.55 & 8.9 & 24 & 43 & 典げ降伏後せん断 \\
\hline$I-2$ & 23.5 & 378.3 & 359.1 & 0.64 & 1.62 & 2.26 & 11.0 & 18 & 36 & 曲け破壞 \\
\hline $1-3$ & 31.9 & 378.3 & 359.1 & 0.68 & 2.74 & 3.42 & 11.2 & 14 & 23 & 鉄朤破断 \\
\hline II -1 & 28.2 & 397.2 & 359.1 & 0.78 & 1.68 & 2.46 & 10.4 & 16 & 36 & 典け破壊 \\
\hline II -2 & 33.6 & 397.2 & 359.1 & 0.80 & 2.61 & 3.40 & 11.3 & 10 & 32 & 鉄㬏破断 \\
\hline III -1 & 32.3 & 359.1 & 359.1 & 1.25 & 2.66 & 3.92 & 24.0 & 0 & 13 & 鉄筋破断 \\
\hline III -2 & 33.7 & 379.1 & 359.1 & 0.69 & 1.08 & 1.77 & 7.3 & 21 & 38 & 曲げ降伏後せん断 \\
\hline III -3 & 32.4 & 378.3 & 397.2 & 0.70 & 3.48 & 4.18 & 10.6 & 12 & 28 & 鉄筋破断 \\
\hline A 1 & 26.4 & 378.4 & 358.3 & 0.65 & 1.39 & 2.05 & 10.5 & 16 & 36 & 曲け破壞 \\
\hline A 2 & 23.3 & 378.4 & 358.3 & 0.64 & 1.89 & 2.52 & 12.4 & 17 & 38 & 曲け破壊 \\
\hline A 3 & 26.8 & 397.2 & 358.3 & 0.77 & 2.16 & 2.94 & 15.1 & 14 & 38 & 曲门破壊 \\
\hline A 4 & 28.4 & 358.3 & 358.3 & 1.09 & 2.78 & 3.86 & 20.6 & 12 & 29 & 曲け破䁲 \\
\hline A 5 & 29.1 & 358.3 & 358.3 & 1.08 & 1.58 & 2.66 & 14.8 & 18 & 42 & 曲け破壊 \\
\hline A 6 & 31.0 & 378.4 & 358.3 & 0.68 & 2.20 & 2.87 & 15.2 & 14 & 34 & 典け破壤 \\
\hline A 7 & 30.7 & 378.4 & 358.3 & 0.68 & 1.83 & 2.51 & 12.6 & 16 & 34 & 曲け破猿 \\
\hline A 8 & 23.8 & 397.2 & 358.3 & 0.75 & 1.23 & 1.98 & 12.1 & 19 & 43 & 曲け破壊 \\
\hline A 9 & 21.7 & 378.4 & 397.2 & 0.63 & 3.31 & 3.94 & 14.5 & 12 & 34 & 曲け破懐 \\
\hline A 10 & 22.3 & 378.4 & 358.3 & 0.66 & 1.35 & 2.01 & 11.9 & 26 & 55 & 典け破壊 \\
\hline A 11 & 24.6 & 378.4 & 358.3 & 0.66 & 1.70 & 2.36 & 13.7 & 15 & 54 & 曲け破壊 \\
\hline No.6 & 19.4 & 375.1 & 358.3 & 0.62 & 1.94 & 2.56 & 13.8 & 15 & 38 & 曹け破壊 \\
\hline
\end{tabular}




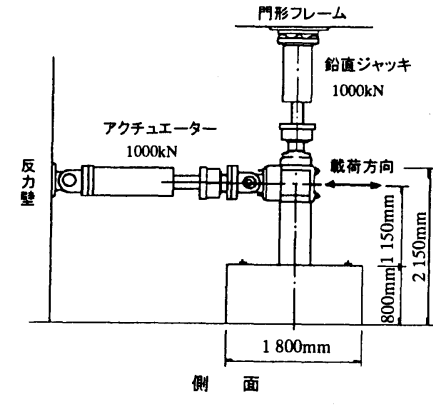

図一 2 載荷装置

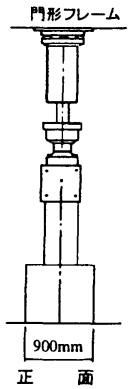

正 面

面図を示す、試験体は，実物のラーメン高架橋柱の $1 / 2$ スケールを想定したものであり，主な試験パ ラメーターは, 断面形状, せん断不パン比 $(\mathrm{a} / \mathrm{d})$; 軸 方向鉄筋比 (pa : $=\Sigma \mathrm{As} /(\mathrm{B} \cdot \mathrm{D})$, ここに $\Sigma \mathrm{As}$; 全軸方向鉄筋の断面積, B; 柱断面幅, $\mathrm{D}$; 柱断面高さ), 帯鉄筋比 $(\mathrm{ps})$ ，軸圧縮応力度（ $\sigma$ 'no）である. 試 験範囲は, 軸方向鉄筋比 (pa) は $0.63 \sim 4.42 \%$, 帯 鉄筋比 (ps) が $0.45 \sim 2.27 \%$, 軸圧縮応力度 $(\sigma$ 'no) は $0.98\left(\mathrm{~N} / \mathrm{mm}^{2}\right)$ を中心に $0.49 \sim 4.9\left(\mathrm{~N} / \mathrm{mm}^{2}\right)$ とした. 表一 2 に材料強度, 耐力比 (Vyd/Vmu : ここに, Vyd ; 部材のせん断耐力, $\mathrm{Vmu} ;=\mathrm{Mu} / \mathrm{la} \mathrm{Mu}$; 曲げ耐力, $1 \mathrm{a}$; せん断スパン）の計算值を示す. 耐力比の計算 ${ }^{1)}$ には, 表一 2 に示した材料試験から定まる実材料強 度を用い, せん断補強筋のない棒部材のせん断耐力

(Vcd）は $\mathrm{a} / \mathrm{d}$ の効果を考慮した二羽ら（a/d ミ2.5） 及び石橋ら（2.5 $\geqq \mathrm{a} / \mathrm{d} \geqq 0.5 ）$ の式 ${ }^{6) ， 7 ） に よ り, ~}$ 部分安全係数はすべて 1.0 として計算した. なお, 今回の試験体の, 耐力比の範囲は 1.55〜4.18 であ る.

また, 補修試験体A 1 (R), A 2 (R), A 3 (R), A 9 (R) は, A 1, A 2, A 3, A 9 試 験体を試験終了後に補修を行ったものである.

\section{（2）載荷方法}

載荷装置の概要を図ー 2 に示す. 載荷は, 軸力 を一定とした静的正負交番載荷試験であり， $1 \delta \mathrm{y}$ までは 4. 9 9. 8kN きざみで荷重制御にて載荷し, 最外縁の軸方向鉄筋ひずみが材料の試験結果から定 まる降伏ひずみに達したときの変位を降伏変位

（ $\delta \mathrm{y} ）$ とした. $2 \delta \mathrm{y}$ 以降は, 降伏変位 $(\delta \mathrm{y})$ の 整数倍の変位毎に変位制御で交番載荷した.

表ー 1 に示した載荷パターン $\mathrm{A}$ は, $1 \delta \mathrm{y}$ 終了後, $2 \delta \mathrm{y}, 4 \delta \mathrm{y} \cdots \cdot$.…降伏変位の偶数倍をそれぞれ 1 サイクルずつ載荷し, 荷重低下が生じた時点から 1 $\delta \mathrm{y}$ ずつ変位を增加させ, 荷重低下後はそれぞれ 3 サイクルの載荷を行った. パターン B は，2 $\delta \mathrm{y}$ 以

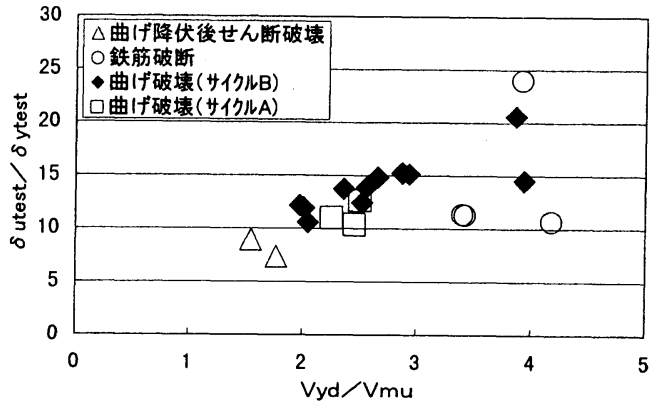

図ー3 耐力比とじん性率の関係

降, $1 \delta \mathrm{y}$ 毎に 1 サイクルずつ載荷を行ったもので ある.

基本載荷パターンを 2 種類としたのは, 当初 $\mathrm{A}$ パターンによる載荷を行っていたが，今回のような じん性率 10 程度以上の大变形領域を対象とした交 番載荷試験では, 軸方向鉄筋が低サイクル疲労によ り破断することがあり, 過去の地震でこのような破 壊形態があまり確認されておらず，その可能性も小 さいという指摘もある11)こと，また，鉄筋が破断 しない場合の変形性能および損傷状態を評価するこ とを目的とし, 後半は B パターンで載荷を行った. また, 補修試験体のCパターンは, Bパターンの 3 $\delta \mathrm{y}, 5 \delta \mathrm{y}, 7 \delta \mathrm{y}$ の載荷を省いたものである. なお, 載荷速度は, 1 サイクル 120 秒を最速とし, 変位が大きくなるに従って, 載荷点での載荷速度の 上限値が $1 \mathrm{~mm} / \mathrm{sec}$ となるよう載荷速度を変更し, 水 平荷重が降伏荷重の $70 \%$ 程度以下となるまで試験を 行った.

\section{3．損傷状況の実験結果}

\section{（1）破壊形態およびじん性率}

表ー 2 に, 破壊形態およびじん性率 ( $\delta$ utest) $\delta$ ytest : ここに, $\delta$ ytest ; 降伏変位の実験修正 值 ${ }^{8)}, \delta$ utest ; 降伏荷重を維持する最大変位=終 局変位の実験值, 図一 4 参照) の実験結果を示す. ここでは, 実験値は処女載荷側の值により整理を行 った. 表一 2 に示した破壊形態で,「鉄筋破断」は 載荷面基部のかぶりコンクリートが剥落したのち, 軸方向鉄筋の一部が破断して終局に至ったものであ る.また,「曲げ降伏後せん断破壊」は, 軸方向鉄 筋降伏後に, 1.5〜2.0D（D：断面高さ）の位置と 圧縮縁基部を結んだ位置に発生したせん断ひび割れ に起因する破壊により終局に至るもので,「曲げ破 壊」は, 軸方向鉄筋降伏後, 基部から $1 \mathrm{D}$ 程度まで の載荷面のかぶりコンクリート剥落後, コアコンク 


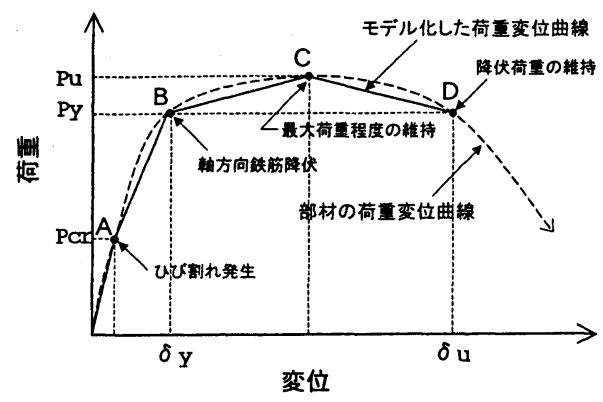

図-4 荷重変位曲線のモデル

リートが徐々に粉砕化され耐力低下し終局に至るも のである.

図一ろは, 耐力比とじん性率の実験結果を示した ものである. 今回対象とした試験体は, 曲げ降伏後 せん断破壊する 2 試験体を除き, 耐力比が概ね 2 以 上に設定されており, じん性率 10 以上の大きな変 形性能を有する部材である. なお, 載荷少仍の違い によりじん性率の実験結果が異なることが指摘され ている ${ }^{8)}$. 今回の場合は, 図ー3に示したように曲 げ破壊したものについて耐力比により分類して比較 すると, 載荷パターンA の試験体のじん性率が, 同 程度の耐力比を有する載荷パターン B の試験体のじ ん性率よりも若干小さめであるが, 大きな差は認め られない.

\section{（2）損偒状況}

図一 4 は, 曲げ降伏後にせん断破壊もしくは曲 げ破壊となる R C 部材の荷重変位曲線の包絡線を模 式的に示したものである. 塑性変形レベルと損傷レ ベルを対応させる設計では, 図に示した $A \sim D$ 点の 塑性変形レベルの分岐点と損傷レベルを対応させる ことが考えられる. 以下に, 今回の試験範囲でのパ ラメータの影響に着目し, 図ー4に示したモデルに 対応させながら損傷状況について述べる.

\section{a) 降伏变位時（図一 4 B点） \\ (1)軸方向鉄筋比の影響}

写真－1（a）はA 2 試験体 $(\mathrm{pa}=2.865 \%)$ の, 写真－1（b）はA 5 試験体 $(\mathrm{pa}=1.267 \%)$ の 1 $\delta \mathrm{y}$ 終了後の状況である. 両試験体では断面形状, 軸圧縮応力度が同一で, 耐力比もほぼ同一である. また, 写真一 1 （c）に軸圧縮応力度以外の諸元は 異なるが今回の試験では軸方向鉄筋比が最大である III -2 試験体（pa=4.424\%）の $1 \delta \mathrm{y}$ 終了後の状 況である.これらのひび割れ発生状況は，ひび割れ 間隔，角度等に若干の相違は見られるが，ほぼ同様 の傾向である.
(2)耐力比（帯鉄筋比）の影響

写真 -1 (d) は I - 1 試験体 $(\mathrm{Vyd} / \mathrm{Vmu}=1.55$, $\mathrm{ps}=0.507 \%$ ）の, 写真 -1 （e ）は I - 3 試験体 $(\mathrm{Vyd} / \mathrm{Vmu}=3.42, \mathrm{ps}=1.584 \%)$ の $1 \delta \mathrm{y}$ 終了後の 状況である. また, 軸力等の諸元も異なるが耐力比 が最大であるIII - 3 試験体 $(\mathrm{Vyd} / \mathrm{Vmu}=4.18, \mathrm{ps}=$ 2. 27\%）の試験結果を写真一（ $f$ ）に示す.これ らにも, ひび割れ本数等は若干異なるものの, ひび 割れ発生状況に大きな相違は見られない.

(3)軸力の影響

写真 $-1 （ \mathrm{~g})$ にII -2 試験体 $\left(\sigma^{\prime} \mathrm{n}_{0}=\right.$ 1. $\left.96 \mathrm{~N} / \mathrm{mm}^{2}\right)$ の, 写真 -1 (h) にA 3 試験体 ( $\sigma^{\prime}$ no $\left.=0.49 \mathrm{~N} / \mathrm{mm}^{2}\right)$ の $1 \delta \mathrm{y}$ 終了後の状況である.これ らについても, 他の条件が若干異なるが軸力が最大 である写真ー1（f）に示したIII－3 試験体（ $\sigma^{\prime}$ no $\left.=4.9 \mathrm{~N} / \mathrm{mm}^{2}\right)$ を含め, 同様にひび割れ発生状況に大 差はない.

(4)せん断スパン比の影響

写真一 1 （i） はA 1 試験体 $(a / d=3.19)$ の, 写真一 $1(\mathrm{j})$ はA 10 試験体 $(\mathrm{a} / \mathrm{d}=1.52)$ の試験 結果である. 両試験体では, 軸圧縮応力度が同一, 耐力比はほぼ同一であり, ひび割れ発生状況にも大 きな差は見られない. また, いずれも曲げ破壊であ りるため $\mathrm{a} / \mathrm{d}$ の影響は少ないものと思われる.なお, 写真－1（c）に示したように, 他の条件は異なる がせん断スパン比が今回の試験範囲で最大である III -2 試験体（ $\mathrm{a} / \mathrm{d}=4.17 ）$ と比較しても特に有為差 は見受けられない。

以上のように，今回の試験範囲では，降伏時に は, ひび割れ本数等は若干異なるものの, ひび割れ 発生状況等に大きな差は認められない. 全体的な損 傷状況の特徴を以下に示す.

降伏時までには, 曲げひび割れが柱の基部から載 荷点近傍までに概ね 150 200mm の間隔で発生する. 柱側面では, 曲げひび割れの先端が部材断面の圧縮 ゾーンに向かって進展し, 部材軸と $45^{\circ}$ 程度の角 度を有する斜めひび割れへと進展するが, ひび割れ 先端は圧縮縁まで到達しない，また，変位を 0 に戻 したときのひび割れはほとんど閉じており，残留ひ び割れ幅は極めて小さい.

\section{b) 最大荷重時（図-4C点） \\ (1)軸方向鉄筋比の影響}

写真－2（a）はA 2 試験体, 写真 - 2（b ) はA 5 試験体, 写真 -2 (c) はIII-2 試験体の最 大荷重後の状況である.

(2)耐力比（帯鉄筋比）の影響

写真 $-2 （ d ） に I-1$ 試験体, 写真 -2 (e) にI-3 試験体, 写真 -2 (f) にIII-3 試験体の 


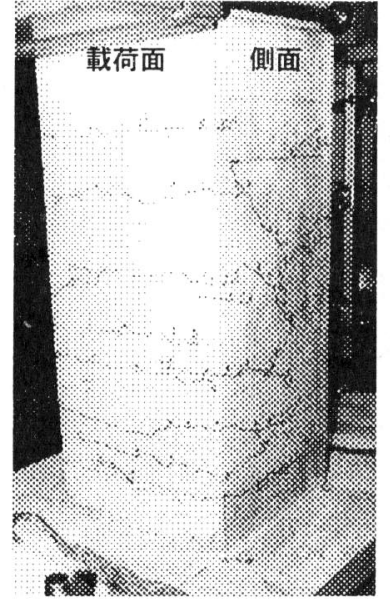

(a) A 2

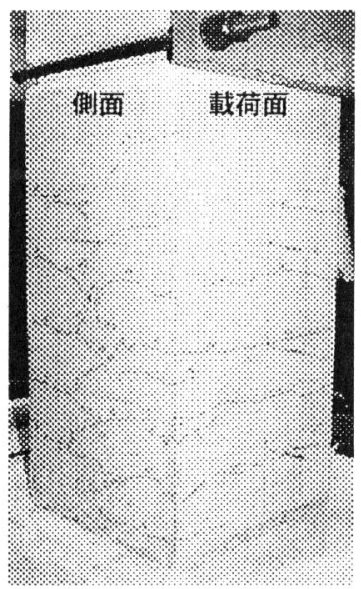

(d) I - I

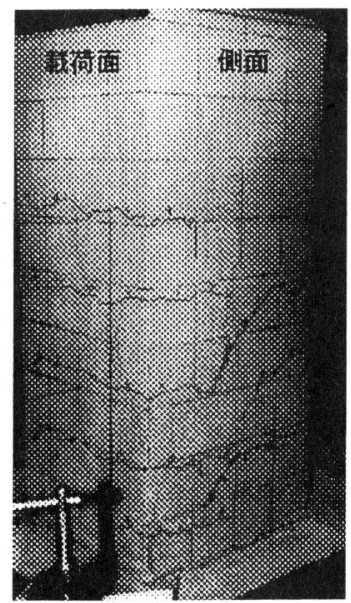

(b) A 5

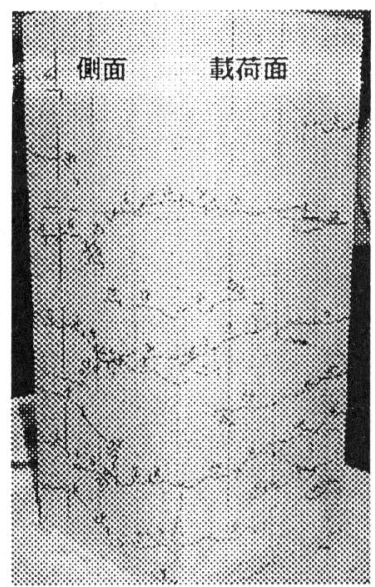

(e) I - 3

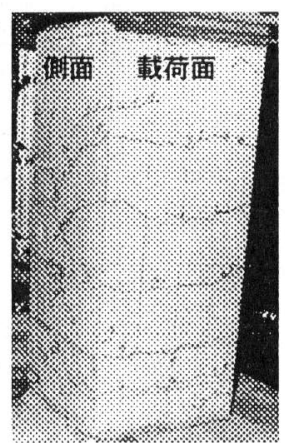

(i) A 1

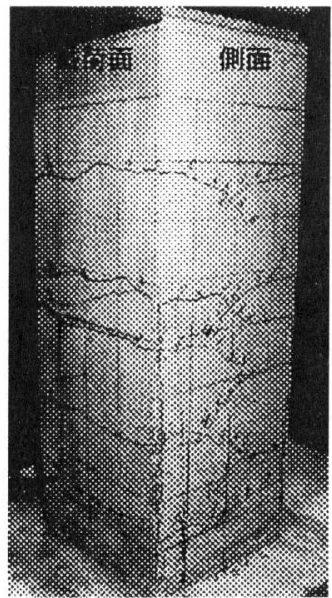

(c) III -2

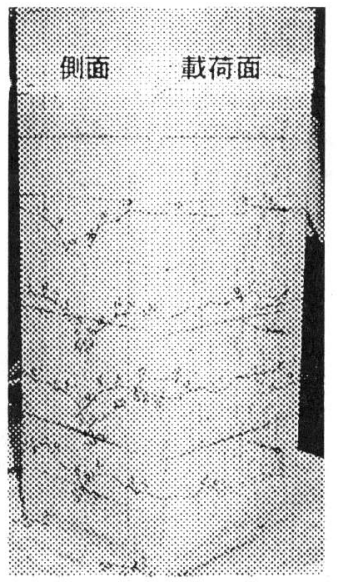

(f) III -3

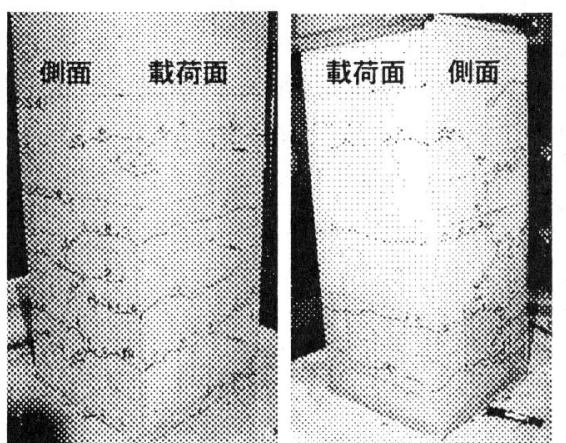

(g) II -2 (h) $\mathrm{A} 3$

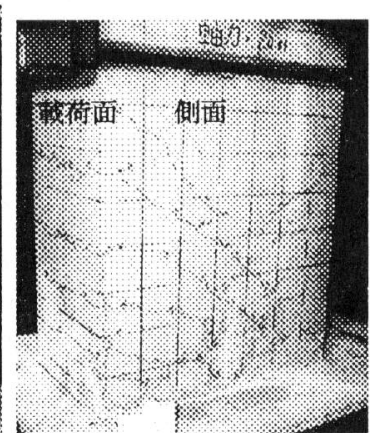

(j) A 10

写真 -1 降伏後の損傷状況 


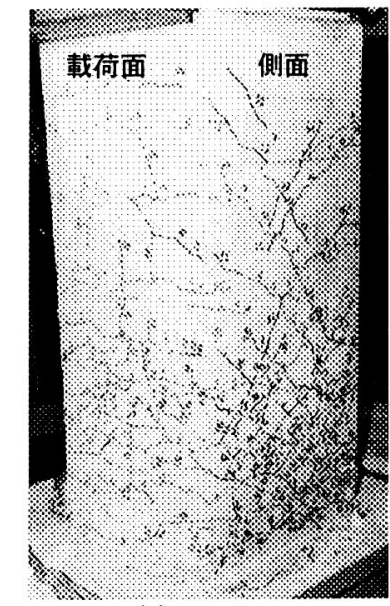

(a) A 2

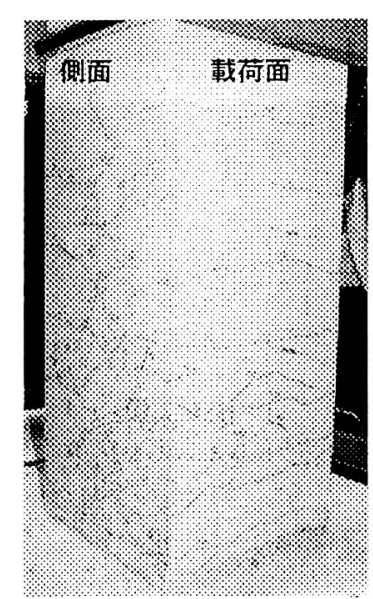

(d) I -1

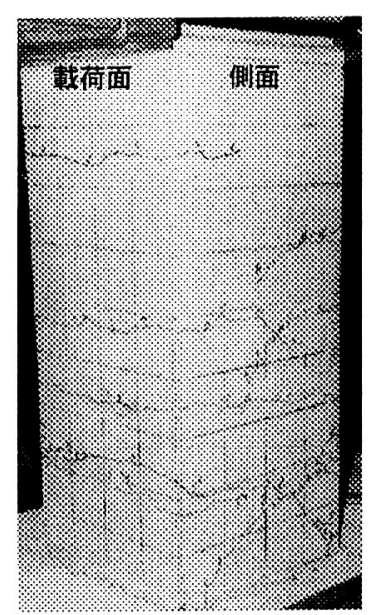

(b) A 5

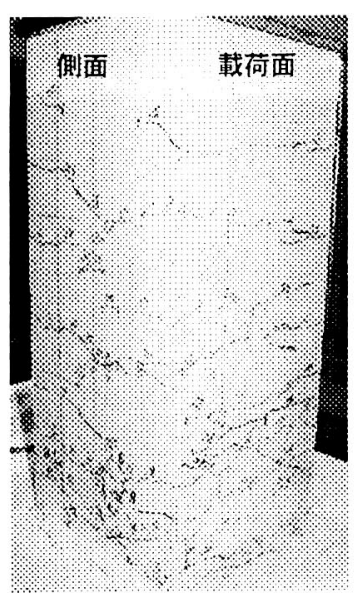

(e) $\mathrm{I}-3$

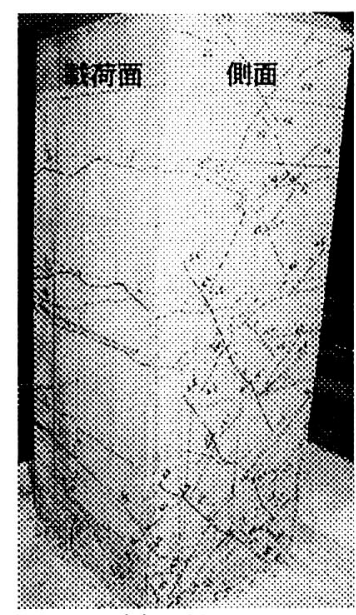

(c) III -2

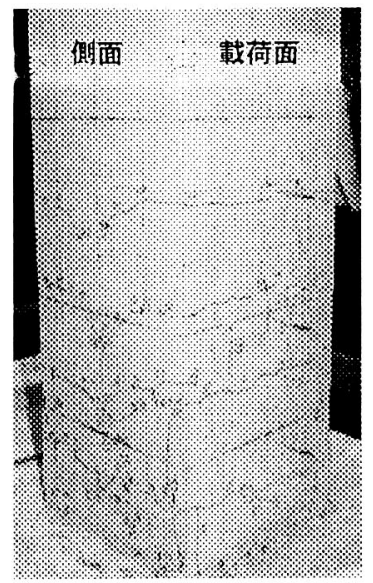

(f) $\quad$ III -3

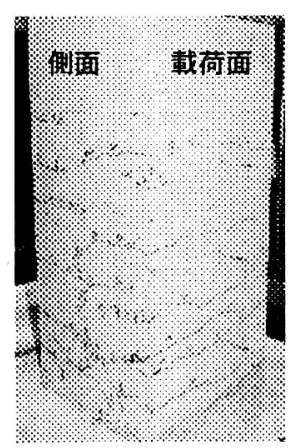

(g) II -2

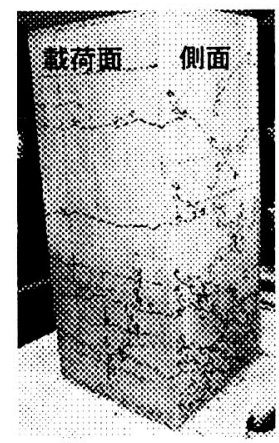

(h) A 3

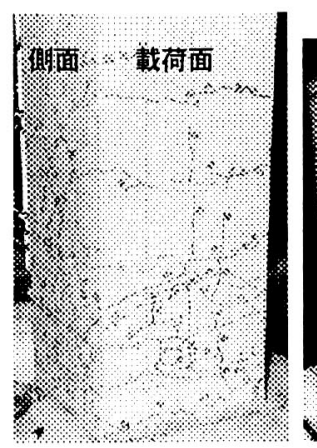

(i) A 1

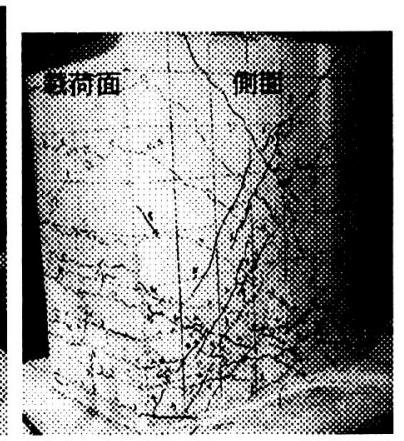

(j) A 10

写真 -2 最大荷重後の損傷状況 


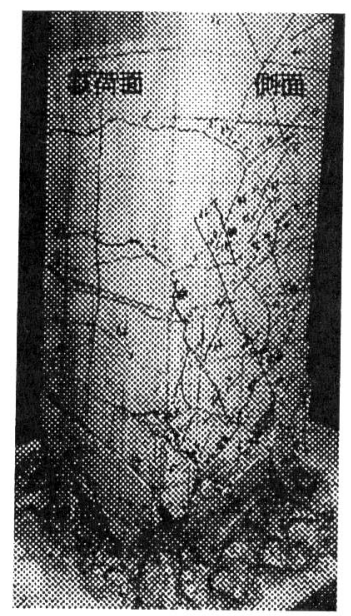

(a) III -2

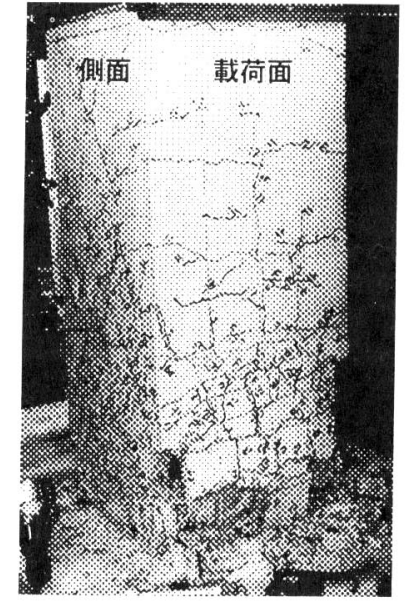

(b) A 1

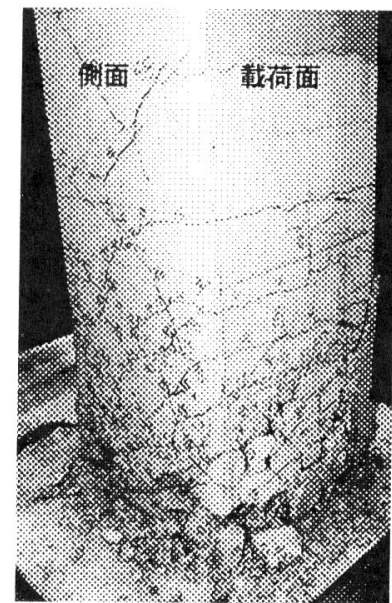

(c) $I-2$

写真 -3 終局後の損傷状況

試験結果を示す.

(3)軸力の影響

写真 $-2 （ \mathrm{~g})$ にII -2 試験体の, 写真 $-2(h)$ にA 3 試験体の最大荷重時の状況を示す.

(4)せん断スパン比の影響

写真-2（i）はA 1 試験体の, 写真 $-2 （ j)$ はA 10 試験体の試験結果である.

最大荷重直後は，破壊形態が曲げ破壊および鉄 筋破断之なる試験体（I－1，III-2 以外）では, 最大荷重時の塑性変形量に大きな差があることから, ひび割れ本数, 進展状況にかなり相違がみられるも のもあった. しかしながら, ひび割れ本数以外の断 面の損傷状態や荷重を 0 に戻したときのひび割れ幅 に顕著な差は見られなかった。一般的な特徵を示す と, 柱側面には, フーチングから高さ $1 \mathrm{D}$ （D：断 面高さ) 程度の位置の引張り縁から載荷点対角の圧 縮縁基部に向かって伸びるせん断ひび割れが圧縮縁 までつながる. 最大荷重時には，ほとんどのせん断 ひび割れの先端が, 載荷点対角の圧縮縁基部周辺ま で達している. 載荷面では, 柱基部から $1 \mathrm{D}$ 程度の 高さまでに曲げひび割れの数が増加する.なお, 載 荷中はフーチング面からの高さ $1 \mathrm{D}$ 付近から, 柱基 部に向かって伸びたせん断ひび割れが, 他のひび割 れよりも大きく開き，これより上方のひび割れはほ とんど開かなくなる.

一方, 曲げ降伏後せん断破壊する試験体（I 1, III-2) では, 載荷中のひび割れは, フーチン グから高さが $1 \mathrm{D}$ よりも高い位置から, 柱基部に伸 びるせん断ひび割れのひび割れ幅が大きくなる.

なお，最大荷重時には荷重を 0 としたときの残 留ひび割れ幅は，破壊形態に関わらず若干大きくな
るが, かぶりコンクリートの浮き上り, 剥離等は生 じない。

\section{C) 終局変位時（図一 4 D点）}

終局時の損傷状況は, 破壊形態別に示す.

(1)曲げ降伏後にせん断破壊する試験体

曲げ降伏後にせん断破壊する I - 1 およびIII 2 試験体はほぼ同様の損傷状況となる．最大荷重以 後の繰り返し載荷により, 柱側面のかぶりコンクリ 一トの損傷が大きくなり，柱基部では剥離する，一 方, 載荷面のかぶりコンクリートも基部において若 干の浮き上り, 剥落が見られるが損傷は側面よりも 軽微である. 耐力は比較的急激に低下する. 写真一 3（a）にIII-2 試験体の終局後の状況を示す. (2)曲げ破壊する試験体

今回の試験範囲においてはパラメータの相違に より損傷状況に有為差は見られない。すすなわち, 曲 げ破壊となる試験体は，柱基部圧縮縁とフーチング から $1 \mathrm{D}$ 程度の高さの引張り縁を結ぶ位置に発生し たせん断ひび割れが卓越する. その後, その正負載 荷によるせん断ひび割れの交点を回転中心として変 形を繰り返すうちに, 載荷面方向のかぶりコンクリ 一トが剥落し，軸方向鉄筋がはらみだすが，変形が 進んでも急激な耐力低下は起きず，損傷の集中する $1 \mathrm{D}$ 程度の区間で圧縮を受けるコアコンクリートが 繰り返し載荷により徐々に粉体化もしくは細粒化し, 耐力が低下する.

一方, 載荷パターンAとBの違いにより, 前述 のようにじん性率の実験值が若干異なるが，終局に いたる, あるいは終局時の損傷状況は今回の試験範 囲ではそれほど相違はない. 載荷パターン以外のパ ラメータがほぼ同一である A 1 試験体と I - 2 試験 
回転中心： h 1

損偒の集中する区間長 : h 2

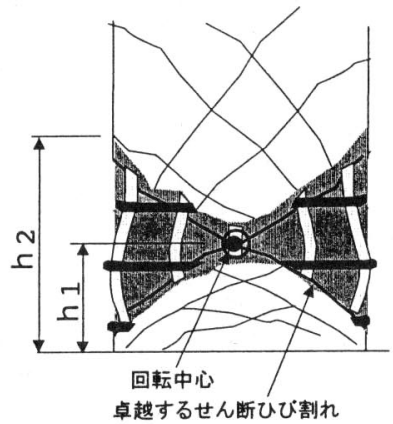

図ー5 かぶりコ沙ート剥落後の損傷状況の概念図

体の終局後の状況を写真－3（b ），（c）に示す．

なお, 曲げ破壊する試験体は, 試験終了後に剥 離, 細粒化したコンクリートをとり除いて内部を観 察すると，模擬的には図ー 5 のような損傷状況であ る．損傷が集中する区間では，柱基部圧縮縁とフー チングから高さ $1 \mathrm{D}$ 付近を結ぶせん断ひび割れによ り内部コンクリートが完全に分断されており，この ひび割れに挟まれる内部コンクリート（図－5中の ハッチング部）が損傷し，くさび状に砕破されてい た.

\section{4. 損傷状況に関する考察}

\section{（1）損傷レベル（補修の容易さ）に対する検討}

損傷状況の実験結果をもとに，図ー4 に示した 塑性変形レベルに対する損傷レベル（補修の容易 さ）の検討を行う.なお，実務的には，構造物の急 激な崩壊を防ぐため, 曲げ降伏後でもせん断破壊し ないよう設計するのが一般的であると思われるので， ここでは，主として破壊形態が「曲げ破壊」のもの を対象とすることとする．また，曲げ破壊の場合， 前章で述べたように今回の試験範囲ではパラメータ の相違による損傷程度の差はほとんどないが，塑性 変形レベルを後述のように無次元化して評価するた めには，じん性率の評価を適正に行う必要があるの で, 載荷サイクルの影響についてのみは比較しなが ら検討を進めることとする.

せん断破壊が先行しない部材において, 地震後 に無補修で供用できるかどうかが損傷レベルの一つ の分岐点となる．前章で述べたように，「降伏時」

「最大荷重時」では，断面の損傷もほとんどなく， 変位が 0 に戻ったときの残留ひび割れ幅も大きくな いので, 断面の損傷状態としては「無補修で供用で きる」状態であると考えられる.

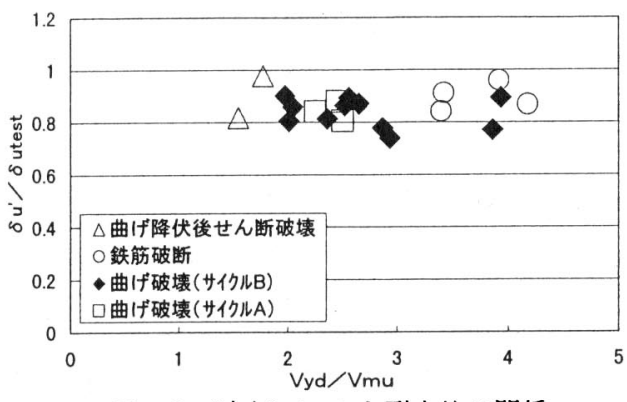

図一 $6 \delta^{\prime} / \delta$ utest と耐力比の関係

次に，断面補修という観点からは，ひび割れ注 入程度でよいか，あるいは断面修復が必要かどうか により損傷レベルの分岐点が設けられると考えられ る. 断面修復が必要となるのは, かぶりコンクリー トが大きく浮き上り, あるいは剥落した後であると 考えられるので, そのような損傷状態に対する塑性 変形レベルでの定量的評価を試みた。ここで,「か ぶりコンクリートが大きく浮き上り，あるいは剥離 した」状態とは, 目視にてそのような状況が認めら れた状態である。厳密には，それより前の段階でか ぶりコンクリートの部分的な浮き上りが生じている ものと思われるが，目視にて大きな浮き上がりが確 認されない場合には，過去の地震災害復旧時におい て，樹脂注入等のみで補修が行われている12，13). これらの補修実績より, 今回もかぶりコンクリート が大きく浮き上り，あるいは剥離した状態となるま では，注入で補修するとした。

図-6は，載荷面のかぶりコンクリートの剥落 が認められた載荷ループの載荷点最大変位 $\left(\delta u^{\prime}\right)$ と, 終局変位 ( $\delta$ utest $)$ の比 ( $\delta \mathrm{u}^{\prime} / \delta$ utest $)$ と 耐力比の関係を示したものである。（ $\delta \mathrm{u}^{\prime} / \delta$ utest）と耐力比には特に相関はない。曲げ破壊と なる試験体については，概ね終局変位（ $\delta$ utest） に対して $80 \sim 90 \%$ 程度の変位の範囲で載荷面のコ ンクリートが剥落することがわかる. また, 載荷パ ターンの差による相違は認められない。なお, 曲げ 降伏後にせん断破壊する場合之，鉄筋破断の場合に は, 終局変位 $(\delta$ utest) の 80〜90\%を越える変位 の範囲で載荷面のコンクリートが剥離している．鉄 筋破断となる試験体の場合は，鉄筋が低サイクル疲 労により破断せずに，曲げ破壊となった場合には， さらに終局変位が大きくなると予想されるので, そ のような場合には今回の鉄筋破断する 4 試験体の諸 元では, コンクリートが剥落するのは, 図に示した よりも小さい変位比となることが想定される.

一方，図一 7 は，断面の損傷が載荷面基部のか ぶりコンクリート表層周辺程度のみに止まる範囲で 


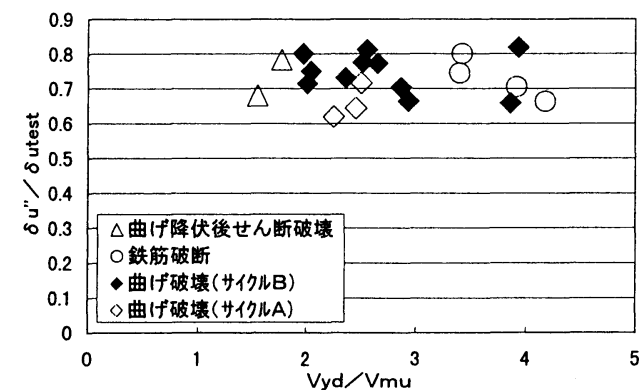

図一 7 $\delta^{\prime \prime} / \delta$ utest と耐力比の関係

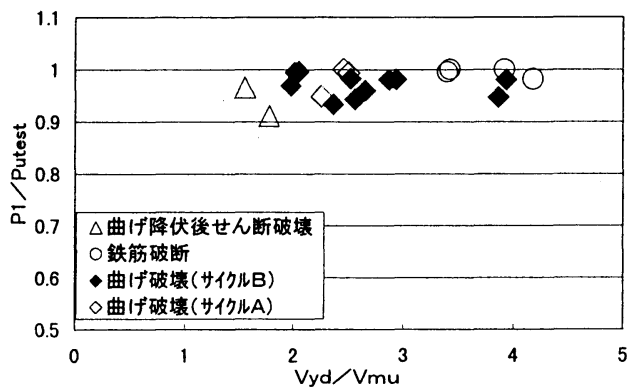

図-8 P1/Putest と耐力比の関係

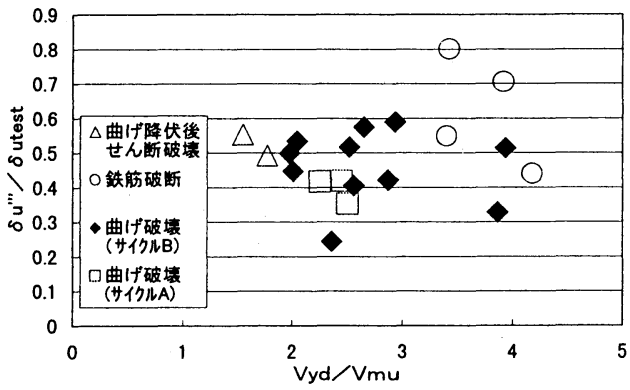

图-9 $\delta \mathrm{u}^{\prime \prime} / \delta \mathrm{utest}$ と酎力比の関係

の載荷点最大変位 $\left(\delta \mathrm{u}^{\prime \prime}\right)$ と終局変位 $(\delta \mathrm{utest})$ の比（ $\delta \mathrm{u}^{\prime \prime} / \delta$ utest） と耐力比の関係を示したも のである，曲げ破壊となる試験体では, 終局変位 （ $\delta$ utest）に対して 60〜80\%程度までの変位まで は, 載荷面基部のかぶりコンクリート表層が若干損 傷する程度であり, 載荷サイクルの影響も見受けら れない，この程度の損傷の範囲内までは，ひび割れ 注入程度の補修で供用できるとしてよいと考えられ る. なお, このループ時の耐力（P1）と最大荷重

(Putest) との比 (P1/Putest) は図-8に示した ように，曲げ破壊する試験体では，載荷サイクルの 影響はほとんどなく, その平均值が 97. 2\%であり, ほとんど最大荷重と大差がない.

図一 9 は, 最大荷重時の変位 $\left.\left(\delta \mathrm{u}^{\prime \prime}\right)^{\prime}\right)$ と終局 変位 ( $\delta$ utest) の比 ( $\delta \mathrm{u}^{\prime \prime}$ ' $/ \delta$ utest $)$ と耐力比 の関係である. 今回の試験では, 作用水平力の測定

\begin{tabular}{|c|c|c|c|c|}
\hline & \begin{tabular}{|l|}
$\delta \mathrm{rpu}$ \\
$/ \delta$ utest
\end{tabular} & $\begin{array}{l}\delta \text { ru } \\
/ \delta \text { utest }\end{array}$ & $\begin{array}{l}\text { Prpu } \\
\text { /Putest }\end{array}$ & \begin{tabular}{|l|} 
Pru \\
/Putest
\end{tabular} \\
\hline$I-1$ & 0.31 & 0.52 & 0.55 & 0.33 \\
\hline III -2 & 0.30 & 0.86 & 0.54 & 0.21 \\
\hline$I-3$ & 0.56 & 0.59 & 0.60 & 0.54 \\
\hline II -2 & 0.37 & 0.80 & 0.49 & 0.36 \\
\hline III -1 & 0.32 & 0.71 & 0.39 & 0.21 \\
\hline III -3 & 0.29 & 0.78 & 0.84 & 0.77 \\
\hline$I-2$ & 0.24 & 0.56 & 0.55 & 0.43 \\
\hline II -1 & 0.26 & 0.62 & 0.45 & 0.34 \\
\hline A7 & 0.20 & 0.73 & 0.46 & 0.28 \\
\hline A1 & 0.35 & 0.71 & 0.49 & 0.44 \\
\hline$\overline{A 2}$ & 0.34 & 0.72 & 0.55 & 0.44 \\
\hline A3 & 0.44 & 0.72 & 0.59 & 0.43 \\
\hline A4 & 0.22 & 0.84 & 0.47 & 0.35 \\
\hline A5 & 0.41 & 0.77 & 0.48 & 0.45 \\
\hline A6 & 0.26 & 0.78 & 0.50 & 0.37 \\
\hline A8 & 0.39 & 0.65 & 0.50 & 0.46 \\
\hline A9 & 0.33 & 0.75 & 0.53 & 0.38 \\
\hline $\mathrm{A} 10$ & 0.22 & 0.73 & 0.43 & 0.15 \\
\hline$A 11$ & 0.10 & 0.62 & 0.28 & 0.41 \\
\hline NO. 6 & 0.26 & 0.73 & 0.51 & 0.48 \\
\hline
\end{tabular}

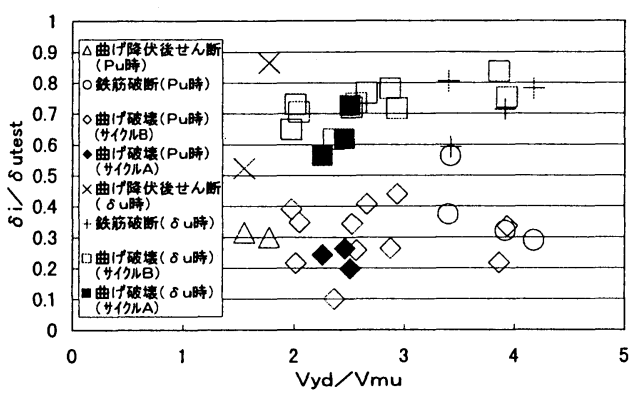

图一-10 $\delta \mathrm{i} / \delta$ utest と耐力比の関係

結果が最大となる点を最大荷重時としている.一方, 荷重包絡線は最大荷重付近で非常になだらかで，最 大荷重点（C 点）があまり明確でないこともあり，

（ $\delta \mathrm{u}^{\prime \prime \prime} / \delta \mathrm{u}$ test）の值はかなりばらつくが, 曲 げ破壊となる試験体では, 載荷サイクルの相違に関 係なく, 最大荷重点 (C 点) の変位は終局変位の $60 \%$ 以下となる. 以上より, 今回のように, 作用水平力 の測定值が最大となる点を「最大荷重時」とした場 合には, 最大荷重直後にかぶりコンクリートが剥落 することはなく, 最大荷重時を越えてからも，かぶ りコンクリートが大きく浮き上るまたは剥離するま での，ほぼ同程度の耐力を維持する範囲では，補修 はひび割れ注入程度でよい，と思われる。

次に, 静的載荷試験の荷重変位曲線における, 最大荷重，および終局時の水平荷重が 0 となるとき の水平変位と, 水平変位が 0 となるときの水平荷重 の比較を行った. 


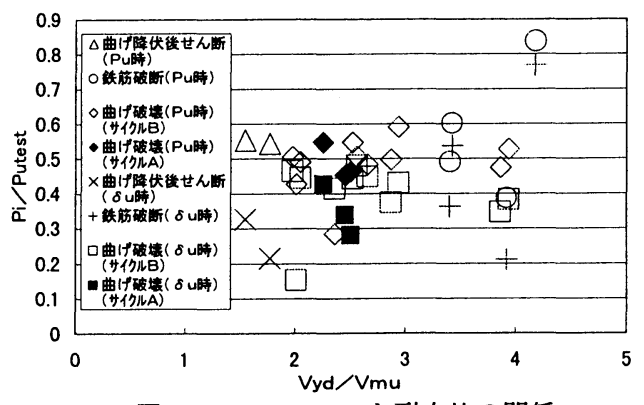

图-11 Pi/Putest と耐力比の関係

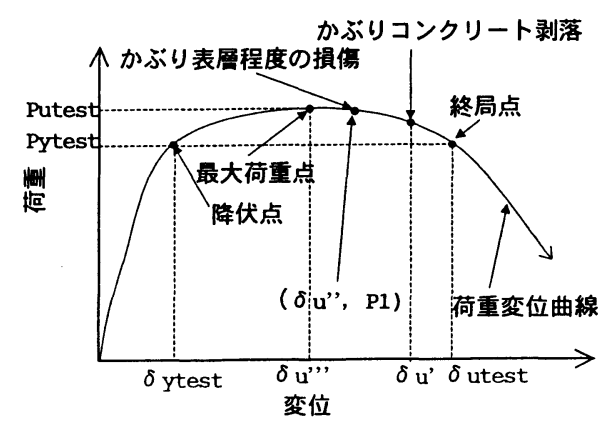

(a) $\delta$ u', $\delta$ u", $\delta$ u'", $\delta$ utest,P1,Pytest,Putest

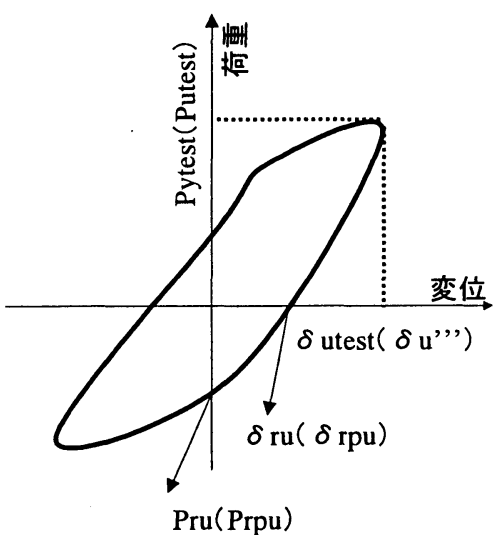

(b) $\delta$ ru,Pru（終局時）および $\delta \mathrm{rpu}, \operatorname{Prpu}$ (最大荷重時) 図-12 各記号の詳細

図ー10 は, 最大荷重時の載荷ループの荷重が 0

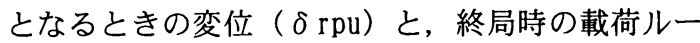
プの荷重が 0 となる時の残留変位（ $\delta \mathrm{ru})$ と終局変 位 ( $\delta$ utest) の比 ( $\delta \mathrm{i} / \delta$ utest $: \delta \mathrm{i}=\delta \mathrm{rpu}$ ま たは $\delta \mathrm{ru}$ ） と耐力比（試験体別の数値を表一 3 に示 す.）の関係を示したものである. 曲げ破壊となる 試験体では, 載荷サイクルの差にほとんど関係なく, 荷重が 0 となるときの変位は終局時が最大荷重時の 概ね 2 倍程度となる. 一方, 図一 11 は, 荷重が 0

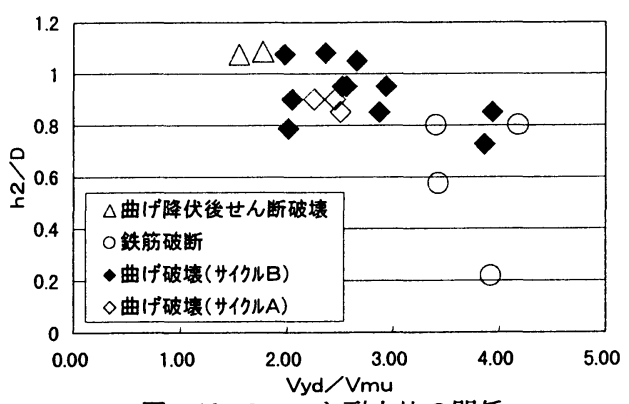

图-13 h2/D と耐力比の関係

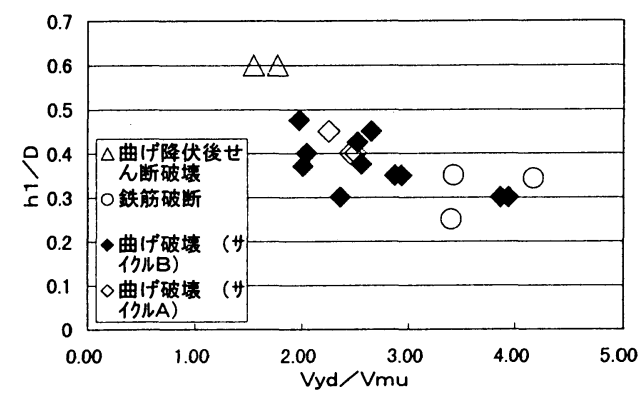

図ー14 hl/D と耐力比の関係

となるときの変位を 0 に戻すために必要な荷重 (Pi) と最大荷重 (Putest) の比 (Pi/Putest) と 耐力比の関係 $(\mathrm{Pi}=\mathrm{Prpu}$ または Pru, Prpu ; 最大 荷重時の載荷ループの荷重が 0 となるときの変位を 0 に戻すために必要な荷重, Pru ; 終局時の載荷ル 一プの荷重が 0 となるときの変位を 0 に戻すために 必要な荷重. 表一 3 に試験体別の数值を示す.）で ある．曲げ破壊する試験体では，載荷パターンの相 違に関係なく, (Prpu/Putest) は 0.5 程度，

(Pru/Putest) は 0.4 程度である. 以上より, 静的 載荷試験における荷重変位履歴経路において, 荷重 が 0 となるときの変位は, 終局時のほうが最大荷重 時の 2 倍程度となるが, その変位を 0 に戻すために 必要な荷重はほとんど同じである.

なお，図ー12 には，上記考察で使用した記号を 示した.

\section{（2）損傷の集中する区間に関する検討}

\section{a ）回転中心と損傷集中区間高さ}

図一 5 の，損傷の模式図に示した損傷集中区間 長（h 2 ）および，卓越するせん断ひび割れの交点 （回転中心）高さ（h 1) と断面高さDの比と耐力 比の関係を図一13，14 に示す.

曲げ破壊する試験体では載荷サイクルの相違の 影響はそれほど見られない. また，(h2/D) と(h1/D) と耐力比はいずれも負の相関が見られ，回転中心高 


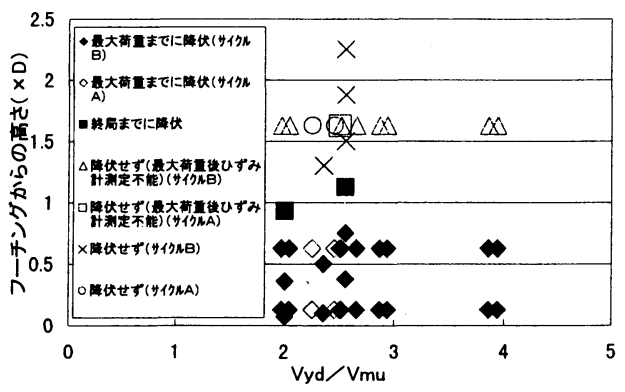

図-15（a）軸方向鉄筋の降伏範囲（曲げ破壊）

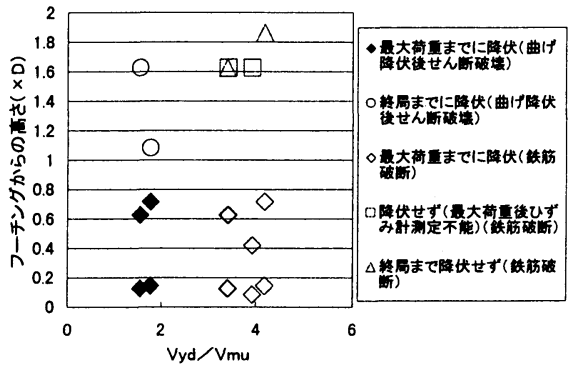

図-15(b) 軸方向鉄筋の降伏範囲 （曲げ降伏後せん断破壊、鉄筋破断）

さh 1 は耐力比 2 付近で $0.45 \mathrm{D}$ 程度であり, 耐力 比の増加に伴い若干小さくなる傾向にある.

\section{b ）軸方向鉄筋の降伏範囲}

図一15（a ），(b ）に，最外縁の軸方向鉄筋が 降伏しているか否かを，ひずみ測定値から判定した ものを示す．図ー15（a）は，曲げ破壊した試験体 の結果, 図一15（b ）は, 曲げ降伏後せん断破壊及 び鉄筋破断した試験体の結果である.

ひずみ測定点は, 図中に示したものがすべてで あり，この結果から主鉄筋の降伏範囲を断定するこ とはできないが，概ね次のような傾向にあると言え る.

曲げ降伏後せん断破壊する場合は, 柱基部から の高さが $1 \mathrm{D}$ を越える範囲で, 最大荷重後, 終局に いたるまでに降伏している．このことは，卓越する 斜めひび割れが柱基部と $1 \mathrm{D}$ を越える位置とを結ぶ 位置に発生していることからも必然的な結果である と言える.

曲げ破壊する場合には，ひずみゲ-ジが終局まで に測定不能となっているものも多く，今回の測定値 から断定することはできないが，1.25D以上では, 降伏したものはない．したがって，今回の試験範囲 では，終局までに概ね $1 \mathrm{D}$ 程度までの最外縁の軸方 向鉄筋は降伏し， $1.25 \mathrm{D}$ 以上では降伏していないよ うである。
表ー4 補修に用いた材料

\begin{tabular}{|c|c|c|}
\hline \multirow{2}{*}{ No } & \multicolumn{2}{|c|}{ 使用 材 料 } \\
\hline & クラック注入 & 断面传得 \\
\hline$A 1(R)$ & エポキシ樹脂 & エポキシ樹脂モルタル \\
\hline$A 2(R)$ & ア夘ル樹脂 & $\begin{array}{l}\text { 超速硬セメシトモルタル } \\
\text { 一部ポリマーセメント } \\
\end{array}$ \\
\hline$A 3(R)$ & $\begin{array}{c}\text { セメト系超微粒子クラッ } \\
\text { ク注入材 }\end{array}$ & ポリマーセメントモルタル \\
\hline$A 9(R)$ & & プレシックスモルタル \\
\hline
\end{tabular}

表 -5 補修の施工順序

\begin{tabular}{|c|c|}
\hline 順 店 & 施 工 内 容 \\
\hline$\overline{(1)}$ & 交番載荷終了後の供試体清掃 \\
\hline (2) & 柱部材のクラック発生状況確認 \\
\hline (3) & クラック注入用治具取付け \\
\hline (4) & 断面修復用型伜組み立て \\
\hline (5) & 断面修復材料練り混ぜ、打設、養生 \\
\hline (6) & 型枠撤去 \\
\hline (7) & クラック注入流失防止用シール貼付 \\
\hline (8) & クラック注入材料練り混ぜ、打設、養生 \\
\hline (9) & 治具、シ一川撤去 \\
\hline
\end{tabular}

\section{5. 補修効果の確認}

\section{（1）補修方法および実験の概要}

試験体諸元は, 表一 1 に示したとおりであり, 補修試験体A 1 (R), A $2(\mathrm{R})$, A $3(\mathrm{R}), \mathrm{A}$ 9 （R）は，載荷試験を終了した A 1, A 2, A 3, A 9 試験体の交番載荷試験終了後, そのまま補修し て用いた.

補修は表一 4 に示した材料を用い，表一 5 に示 した順序で行った．表一 6 は材料強度である. 補修 は, 粉砕したコンクリートがらを取り除き, 軸方向 鉄筋，帯鉄筋は整形せずにはらみ出したもの，また は変形したものもそのまま用いた．A 2（R），A 3（R），A 9（R）試験体については, 軸方向鉄 筋のはらみだしが大きく, 元の断面形状 $(400 \times 400$ $\mathrm{mm}$ ）への修復が困難であったため, A 2 (R) に ついてはフーチング上面から $350 \mathrm{~mm}$ の範囲で 440 $\mathrm{mm}$ (載荷面) $\times 470 \mathrm{~mm}$ (側面), A 3 （R）はフ 一チング上面から $315 \mathrm{~mm}$ の範囲で $440 \mathrm{~mm} \times 440 \mathrm{~mm}$ に, A 9 (R) はフーチング上面から $450 \mathrm{~mm}$ の範 囲で $415 \mathrm{~mm} \times 470 \mathrm{~mm}$ にそれぞれ断面を増加させた。

なお，載荷は，軸方向鉄筋がすでに降伏してい るため, 補修前の降伏変位の実験值（ $\delta \mathrm{y} ）$ を基準 変位として, 変位制御にてその整数倍の変位の交番 載荷を行った. 
表 -6 補修材料強度

\begin{tabular}{|c|c|c|c|c|c|c|c|c|}
\hline \multirow[b]{2}{*}{ 試験項目 } & \multirow[b]{2}{*}{ 単位 } & \multicolumn{3}{|c|}{ クラック注入材 } & \multicolumn{4}{|c|}{ 断面修復材 } \\
\hline & & エポキシ樹脂 & アクルル樹脂 & $\begin{array}{l}\text { セメン孫超微粒 } \\
\text { 子クラック注入材 }\end{array}$ & $\begin{array}{c}\text { エポキシ樹脂 } \\
\text { モルタル }\end{array}$ & $\begin{array}{c}\text { 超速硬セメント } \\
\text { モルタル }\end{array}$ & $\begin{array}{c}\text { ポリマーセメント } \\
\text { モルタル }\end{array}$ & $\begin{array}{l}\text { プレシックス } \\
\text { モルタル }\end{array}$ \\
\hline 粘 度 & cps & 560 & & 500 & & & & \\
\hline 比重 & & 1.22 & 1.18 & & 1.6 & & & \\
\hline 圧縮強度 & $\mathrm{N} / \mathrm{mm}^{2}$ & 66.7 & & $20.4 \sim 24.5$ & 47.5 & 46.0 & $35.7 \sim 40.8$ & 56.8 \\
\hline 曲げ強度 & $\mathrm{N} / \mathrm{mm}^{2}$ & 56.8 & 66.5 & & 19.4 & & & \\
\hline 引張強度 & $\mathrm{N} / \mathrm{mm}^{2}$ & 37.4 & & & & & & 4.0 \\
\hline
\end{tabular}

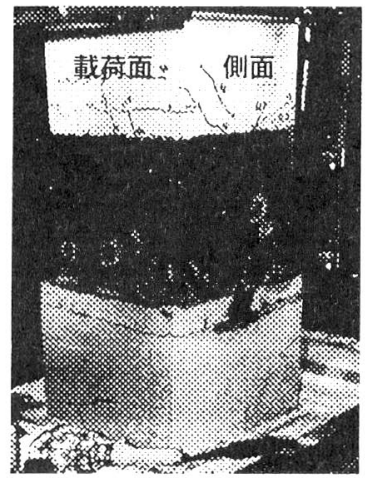

（a）降伏後

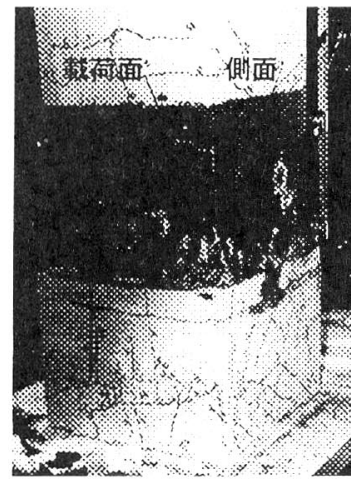

（b）最大荷重後

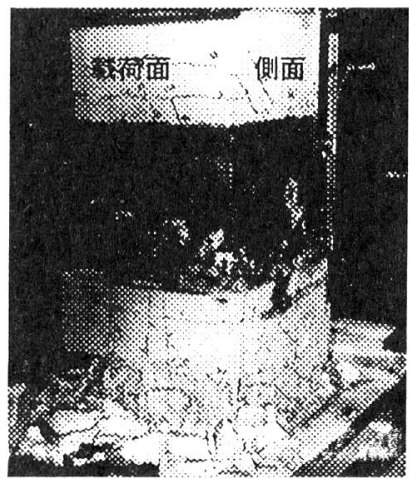

（c） 終局後

写真－4補修試験体（A２（R））の損傷状況

\section{（2）試験結果および考察}

\section{a ）損傷状況}

補修した試験体の損傷状況はいずれも同じような 傾向であったので，ここではA 2 （R）の損傷状況 を述べる.

写真－4（a）に, A 2 (R) の $1 \delta \mathrm{y}$ 終了 （ $\delta \mathrm{y}$ は，A 2 の実験值）時の状況を示す. $1 \delta \mathrm{y}$ 終了後には, 断面修復材料が当初断面のコンクリー トに比べて強度が高いためか, 補修部のひび割れ発 生は軽微である. 写真一 4（b）は, 最大荷重直後 である. 最大荷重直後には, 補修前のA 2 試験体の 試験時（以下，処女載荷試験時という.）と同様に, 柱基部とフーチングから高さ $1 \mathrm{D}$ 程度の位置とを結 ぶ斜めひび割れが卓越し，このひび割れの開口が大 きくなる. 写真－4（c） は，A 2（R）の終局時 の状況である．最大荷重後は，処女載荷試験時と同 様に柱基部と高さ $1 \mathrm{D}$ 程度の位置を結ぶせ九断ひび 割れの交点を回転中心として変形を繰り返し，ひび 割れに挟まれた部分（図－5中にハッチングで示し た箇所）が徐々に粉砕され耐力が徐々に低下し終局 にいたっており，破壊形態は曲げ破壊であった。な お, A 2 （R）以外の補修試験体は, 最大耐力以後 にいずれも，低サイクル疲労による軸方向鉄筋の破 断により終局に至った.

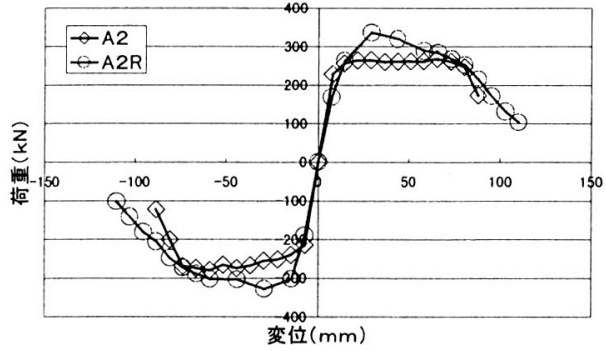

図ー16 A2 および A2 (R)の荷重変位包絡線

\section{b ) 変形性能}

図ー16に，軸方向鉄筋の破断しなかったA 2 （R）と，A２の荷重変位包絡線の比較を示す．鉄 筋破断で終局に至った他の試験体も, 最大荷重以後 の鉄筋破断による耐力低下が若干急激であることを 除き，傾向はA 2（R）とほぼ同様である。すなお ち, 補修試験体は処女載荷時よりも初期剛性が若干 小さいが，補修により基部の断面を増加させている こともあり，最大荷重はプレミックスモ夘ルで断面修 復の夕行った A 4 （R）を除き補修後のほうが大き い.表一 7 は，実験結果をまとめたものであり，表 中の「初期剛性比」「最大荷重比」「等価粘性減衰定 
表 -7 補修供試体の実験結果

\begin{tabular}{|c|c|c|c|c|c|c|}
\hline & 初期剛性比 & 最大荷重比 & じん性率 & 等価粘性減衰定数比 & エネルギー吸収量比 & 破壊形能 \\
\hline $\mathrm{A} 1$ & 1.00 & 1.00 & 10.50 & 1.00 & 1.00 & 㤟け破壊 \\
\hline$A 1(R)$ & 0.77 & 1.19 & 13.40 & 0.90 & 2.83 & 鉄筋破断 \\
\hline A2 & 1.00 & 1.00 & 12.40 & 1.00 & 1.00 & 曲げ破壊 \\
\hline$A 2(R)$ & 0.78 & 1.27 & 10.10 & 0.77 & 1.20 & 曲げ破壊 \\
\hline A3 & 1.00 & 1.00 & 15.10 & 1.00 & 1.00 & 曲げ破壊 \\
\hline$A 3(R)$ & 0.91 & 1.19 & 9.60 & 0.75 & 0.86 & 鉄筋破断 \\
\hline A9 & 1.00 & 1.00 & 14.50 & 1.00 & 1.00 & 曲げ破壊 \\
\hline$A 9(R)$ & 0.67 & 1.08 & 8.90 & 0.65 & 0.98 & 鉄霄破㽤 \\
\hline
\end{tabular}

数比」「エネルギー吸収量比」は，それぞれ処女載 荷時の実験値に対する比である.ここで, 補修後の じん性率を算出する際に, 補修後の終局変位は処女 載荷試験時の降伏荷重を維持できる最大変位とし, 補修後の降伏変位は処女載荷試験時の降伏変位の実 験修正值 $\left(\delta \mathrm{ytes} \mathrm{t}^{5)}\right)$ を初期剛性の低下率で補正 した值とした.なお, 初期剛性は, 降伏点（補修試 験体においては処女載荷時の降伏変位となる点）の 割線剛性とした。また, 等価粘性減衰定数の比は, 処女載荷時と補修試験体の $1 \delta \mathrm{y}$ 時, $2 \delta \mathrm{y}$ 時, $\cdots$ の, 各載荷ループでの値の比を平均したものである. 表一 7 に示すように, 前述の定義で補修後のじん性 率を算定すると, 処女載荷時よりも部材のじん性率 はやや小さ目となるが，鉄筋が破断しない場合には じん性率 10 程度確保できる.

また, 補修後は, 処女載荷試験時と比べて, 各 サイクルの等価粘性減衰定数は低下し, 特に, プレ ミックスモルタルで断面修復のみを行い, ひび割れ 注入を行っていないA 9 （R）試験体で, その低下 率が大きい。しかしながら，等価粘性減衰定数は若 干低下するものの, 終局までの吸収工神代 -は, 鉄筋 が破断しない場合には処女載荷時よりも大きい。 ま た, 実際の地震動の繰り返しでは低サイクル疲労に よる鉄筋破断の可能性は低いという報告 ${ }^{11}$ ももある. したがって, 塑性率 10 程度の大変性で損傷した $\mathrm{R}$ C 柱も, 断面修復とひび割れ注入を行うことにより, 補修前と同等の耐震性能が確保できると思われる.

\section{6. まとめ}

\section{（1）損傷状況について}

今回の実験範囲（f'ck（コンクリート設計基準 強度） $=19.4 \sim 33.7 \mathrm{~N} / \mathrm{mm}^{2}$, fsy（軸方向鉄筋降伏強 度） $=358.3 \sim 397.2 \mathrm{~N} / \mathrm{mm}^{2}, \quad \mathrm{fwy}$ （帯鉄筋降伏強度） $=358.3 \sim 397.2 \mathrm{~N} / \mathrm{mm}^{2}, \mathrm{a} / \mathrm{d}$ (せん断スパン比) $=1.52$ $\sim 4.17$, pa（軸方向鉄筋比） $=0.634 \sim 4.424 \%$, ps (帯鉄筋比) $=0.453 \sim 2.270 \%, \sigma \sigma^{\prime}$ no（軸圧縮応
力度） $=0.49 \sim 4.9 \mathrm{~N} / \mathrm{mm}^{2}$, 載荷パターン=表 -1 ) における鉄道ラーメン高架橋柱を対象とした RC 柱 の正負交番載荷試験結果から, 部材の塑性変形レベ ルと損傷程度についてまとめると以下のようになる。 なお，「曲げ破壊する試験体」については，今回の 試験範囲は, $\mathrm{a} / \mathrm{d}$ (せん断スパン比) $=1.52 \sim 3.19$, $\mathrm{pa}$ (軸方向鉄筋比） $=1.267 \sim 2.865 \%$, ps（帯鉄筋 比 $)=0.453 \sim 1.267 \%, \sigma^{\prime}$ no (軸圧縮応力度 $)=0.49$ $\sim 0.98 \mathrm{~N} / \mathrm{mm}^{2}$ となる.

a ）降伏時には，曲げ，せん断ひび割れが発生する が，変位を元に戻したときの残留ひび割れ幅は極め て小さく, この程度の損傷までは, 無補修で供用で きると考えられる.

b ）最大荷重時には，荷重を 0 としたときのひび割 れ幅, 変位はある程度残留するものの, 目視で判断 できるコンクリートの大きな浮き, 剥離は生じない. したがって, 過去の地震復旧例によると, 補修程度 は，無補修かまたはひび割れ注入程度でよいと思わ れる.なお，曲げ破壊となる試験体の最大荷重とな る時の変位は, 終局変位の $60 \%$ 程度以下である.

c）曲げ破壊となる場合，変位が終局変位の 60 $80 \%$ 程度までは, 載荷面基部のかぶりコンクリート 表層が若干損傷する程度で, この時点までの補修は, ひび割れ注入程度でよいと考えられる．また，この 時点までは, 水平荷重は最大荷重の $97 \%$ 程度を保 持する.

d）曲げ破壊となる場合，かぶりコンクリートの剥 落は, 変位が終局変位の $80 \sim 90 \%$ 程度で生じる. これ以降の補修は断面修復が必要である.

e ）曲げ破壊となる場合，終局時には，塑性ヒンジ 区間のかぶりコンクリートが剥落, 軸方向鉄筋のは らみだしが生じており補修は断面修復が必要である. 
静的載荷試験の荷重変位履歴経路において, 終局時 の荷重が 0 となるときの変位は, 最大荷重時の, 荷 重が 0 となる時の変位の 2 倍程度まで大きくなるが, 水平変位を 0 に戻すときの荷重は最大荷重時と大差 がない.

g）曲げ破壊となる場合，柱基部の椇傷が集中する 長さ h 1 , 卓越するせん断ひび割れの交点（回転中 心）高さ h 2 と, 柱断面高さDの比（h1/D および h2/D）は, 耐力比と負の相関を持ち, 回転中心は, 耐力比 2 付近で $0.45 \mathrm{D}$ 程度である.

h）曲げ降伏後せん断破壊する場合, 最外縁の軸方 向鉄筋は，卓越する斜めひび割れが柱基部から $1 \mathrm{D}$ 以上の高さに発生するため, 柱基部から 1.5D 程度 以上の高さまで降伏する．また，曲げ破壊の場合に は, 今回の場合, ひずみ計の設置箇所や測定精度の 関係上，断定的なことは言えないが，柱基部から 1 D 程度までは終局までに降伏し，1.25D 程度以上の 高さでは終局時でも降伏していないようである.

\section{（2）補修試験体の変形性能}

a）補修試験体の終局変位を処女載荷試験時の荷重 を維持する最大変位, 降伏変位を処女載荷試験時の 降伏変位を初期剛性の低下率で補正した值として, 補修試験体のじん性を評価すると, 処女載荷試験時 よりは若干変形性能が下回る結果となるが, 軸方向 鉄筋が低サイクル疲労により破断しない場合には, じん性率は 10 程度確保できる.

b) 等価粘性減衰定数は, 補修後が 10 ～ $25 \%$ 程度 低下し，プレミックスモルタルで断面修復のみ行った試 験体では $35 \%$ 程度低下するが, 終局までの吸収工祅 ギ 一は, 鉄筋が破断しない場合, 補修後も処女載荷 試験時と同等以上である.

c ）塑性率 10 程度以上の大変形により損傷を受け た R C 柱は, 今回の試験範囲では, 断面修復, ひび 割れ注入による補修により, 処女載荷時と同等の耐 震性能が確保できる.

謝辞 : 実験結果をまとめるにあたり, 松田芳範氏, 中山弥須夫氏, 海原卓也氏 (以上, 東日本旅客鉄道 株式会社）にご尽力いただいた。ここに記して謝辞 といたします。

付記 : $\left\lceil\delta\right.$ ytest ; 降伏変位の実験修正值 $\left.{ }^{8)}\right\rfloor$

本文では, 柱とフーチングの境の位置での, 最外
縁の主鉄筋ひずみ測定值が，材料試験から定まる鉄 筋の降伏ひずみに達するときを「降伏」とし，その 時の変位を基本的には「反ytest」とした。一方, 実験においては，コンクリート打設等により，柱と フーチングの境の位置の鉄筋ひずみゲージが実験当 初より測定不能となっているものもあり，そのよう な試験体については, フーチング天端から- $50 \mathrm{~mm}$ の 位置のフーチング内の鉄筋ひずみ計の測定值が降伏 ひずみに達したときを便宜的に「降伏」とし実験を 行った. しかしながら, この場合, 柱とフーチング の境ではすでに鉄筋が降伏しており，「降伏変位」 として本文で定義したものより大きな值を得ること となる. そこで, このような場合には, フーチング 天端位置での主鉄筋ひずみを材料試験から定まる降 伏ひずみとしたときの, フーチング内のひずみ分布 を島らの提案する $\tau-s-\varepsilon$ 関係式 ${ }^{10)}$ から求め, フーチング天端位置から-50m でのひずみ測定值が, ひずみ解析值と等しくなるときを「降伏」とし，そ の時の変位を「 $\delta$ y test ; 降伏変位の実験修正值」 として取り扱った. なお, 島らの提案する $\tau-\mathrm{s}-$ $\varepsilon$ 関倸式から求めたフーチング内のひずみ分布の解 析値と実験值との整合性は別途確認している ${ }^{8)}$.

\section{参考文献}

1) 鉄道構造物等設計標準・同解説 コンクリート構造物 : 運輸省鉄道局監修, 鉄道総合技術研究所編, 丸善株 式会社, 1992 年 10 月.

2 ) コンクリート標準示方書 耐震設計編: 土木学会, 1996 年.

3）鉄道構造物等設計標準・同解説 耐震設計（案）：鉄 道総合技術研究所, 1998 年 11 月.

4）津吉毅, 小林将志, 石橋忠良：正負交番載荷を受け る R C 柱の損傷状況, コンクリート工学年次論文報 告集, Vol. 21，No. 2，1999 年7月.

5 ）海原卓也, 石橋忠良, 松田芳範, 小林薫 : 大変形領 域交番載荷により損傷した R C 柱の補修効果に関す る実験結果, 第 2 回「耐震補強・補修技術, 耐震診 断技術に関するシンポジウム」講演論文集, 土木学 会, 1998 年 7 月.

6 ) 二羽淳一郎, 山田一宇, 横沢和夫, 岡村甫 : せ九断 補強鉄筋を用いない $\mathrm{RC}$ はりのせん断強度式の再評価, 土木学会論文集, 第 372 号/V-5, pp. 167-176, 1986 年 8 月.

7 ）石橋忠良, 松田好史, 齋藤啓一: 少数本のくいを用 いたフーチングのせん断設計について, 土木学会論 文報告集, 第 337 号/ $-5,1983$ 年 9 月.

$8 ）$ 海原卓也, 小林薰, 石橋忠良: 帯鉄筋比の大きい $\mathrm{RC}$ 柱の地震時降伏変位算定法に関する研究, コンクリ 
一ト工学年次論文報告集, Vol. 21, No. 2, 1999 年 7 月.

9 ) 町田篤彦, 睦好宏史, 豊田和彦 : 鉄筋コンクリート 部材の塑性変形能定量化に関する研究, 土木学会論 文集, 第 378 号/V-6, pp. 203-212, 1987 年 2 月.

10）島弘, 周礼良, 岡村甫 : マッシブなコンクリートに 埋め込まれた異形鉄筋の付着応力ーすべりーひずみ 関係, 土木学会論文集, 第 378 号/V-6, 1987 年 2 月.
11）日本コンクリート工学協会 :「塑性域の繰り返し劣化 性状」に関するシンポジウム委員会報告書, pp. 108, 1998 年 8 月.

12）せんかんこう'78 宮城県沖地震特集号 : 日本国有鉄 道, 仙台新幹線工事局, pp. 15-46, 1979 年 12 月.

13）阪神・淡路大震災と鉄道〔第一編 被害と復旧〕：東 日本旅客鉄道株式会社, pp. 229-235, 1996 年 3 月.

\title{
AN EXPERIMENTAL STUDY ON DAMAGE LEVELS AND REPAIRING EFFECTS OF REINFORCED CONCRETE COLUMNS SUBJECTED TO REVERSAL CYCLIC LOADING WITH LARGE DEFORMATIONS
}

\author{
Tadayoshi ISHIBASHI, Takeshi TSUYOSHI, Kaoru KOBAYASHI \\ and Masashi KOBAYASHI
}

\footnotetext{
It is necessary to estimate damage levels of RC columns precisely in large plastic deformation range for reasonable seismic resistant design. We carried out reversal cyclic loading tests by RC model columns with large deformation capacities, and estimated damage levels correspond to plastic deformation levels in consideration for easiness of repairs. Furthermore, ranges of serious damages were examined. We also carried out reversal cyclic loading tests by repaired RC model columns, and repairing effects were confirmed. From these experiments and examinations, damage levels for seismic resistant design and repairing effects of RC columns in large plastic deformation range were made clear.
} 